\title{
The Nutritive Value of Coconut Toddy
}

\author{
By P. C. LEONG \\ Department of Chemistry, University of Malaya, Singapore
}

(Received 2 I November 1952)

The partly fermented sap of the coconut palm (Cocos nucifera), called toddy in Malaya, is a popular drink among certain sections of the population in south-east Asia and among the natives of the central Pacific Islands. The methods of obtaining toddy from various species of palm have been described in detail by Gibbs ( $\mathrm{I}$ II I) and by Browning \& Symons (1916), so that only a brief account need be given here. The young inflorescence is tightly bound with twigs and beaten with a weighted wooden mallet, morning and evening, for a number of days. When the inflorescence begins to ooze its sap, the tip is cut and the sap allowed to trickle into an earthenware pot. Owing to the yeasts and other organisms already present in the used pots, alcoholic and other fermentations begin immediately. Each morning and evening a 'tapper' climbs the tree to collect the toddy, and at each visit he shaves off a fine transverse section of the inflorescence so as to leave a new oozing surface. The fermented toddy, which is milky in appearance, is brought to the Government toddy-shops for sale within a few hours of collection. It is estimated that in the two large towns of Malaya, Singapore and Kuala Lumpur, the quantities sold daily are approximately 400 and 800 gal., respectively; owing to the great demand, each person is allowed to purchase only I pt. at a time.

There is a widespread belief that coconut toddy is a rich source of the B-complex vitamins on account of the yeast present, although there appears to be no experimental evidence in support of this view. On the other hand, the vitamin $B_{1}$ content of coconut toddy was reported as $<5$ i.u./roo g (Anonymous, 194I). Browning \& Symons (1916) isolated from fermented coconut toddy several strains of Saccharomyces cerevisiae, together with other forms that resembled S. ellipsoideus, Schizosaccharomyces mellacei, Zygosaccharomyces barkeri and Saccharomycodes ludwigii. No species of Mycoderma or Torula or film-forming yeast was found.

Availability studies have indicated that thiamine in live yeast is poorly utilized by human subjects (Parsons, Williamson \& Johnson, 1945; Hochberg, Melnick \& Oser, 1945; Kingsley \& Parsons, 1947). There is also evidence that the physiological availability of riboflavin in live yeast is low (Price, Marquette \& Parsons, 1947). Since coconut toddy as normally consumed contains yeast cells that are mostly alive (the period of fermentation varying between $\mathrm{I} 2$ and $24 \mathrm{~h}$ ), it follows that its nutritive value as a source of thiamine and riboflavin will reside mainly in the fluid (i.e. the yeast-free) portion. A study was therefore carried out to determine the distribution of these two vitamins between the yeast cells and the fluid portion of toddy. The investigation was also extended to include the distribution of nicotinic acid, calcium and iron between the two fractions. In addition, whole toddy was also analysed for its major food components and for acidity and alcohol content. 


\section{EXPERIMENTAL}

\section{Materials}

Samples from a Government toddy-shop were analysed as purchased, so that the results would be representative of toddy as consumed. The specimens were purchased during the afternoon sale and brought to the laboratory without delay for analysis.

The two fractions of toddy, namely the yeast cells and the liquid portion, were prepared for analysis in the following manner. Suitable quantities were centrifuged at $1500 \mathrm{~g}$ for $20 \mathrm{~min}$ and the required volume of supernatant liquid was taken for analysis. The yeast residue from a known volume of toddy was washed with distilled water and again centrifuged. The wash liquid was rejected and the residue used for analysis. The relative volumes of yeast cells and supernatant liquid were found to be as $2: 98$ and the concentration of the nutrients in the fluid portion was calculated on this basis.

\section{Methods of assay}

Major components of whole toddy

Acidity was determined by titration with $\mathrm{O} \cdot \mathrm{I} \mathrm{N}-\mathrm{NaOH}$ (phenolphthalein as indicator) and alcohol by distilling $100 \mathrm{ml}$. samples as described by the Association of Official Agricultural Chemists (1950), after fixing the volatile acids by the addition of $5 \mathrm{ml}$. N-NaOH. Ash was determined by incinerating the dried toddy at $500^{\circ}$ for $4 \mathrm{~h}$, total nitrogen by the Kjeldahl method and fat by extraction with diethyl ether after absorbing the toddy samples on fat-free filter paper. Invert sugar was determined by the Lane \& Eynon (1923) volumetric method after clarification with $\mathrm{ZnSO}_{4}$ followed by $\mathrm{NaOH}$. Sucrose was determined by the same method after inversion, which was carried out by treating a portion of the $\mathrm{Zn}(\mathrm{OH})_{2}$ filtrate with conc. $\mathrm{HCl}$ for $\mathrm{I} 8 \mathrm{~h}$ at room temperature.

\section{$B$-vitamins and minerals in the yeast cells and the fluid portion of toddy}

Thiamine. This was estimated by the thiochrome method by means of a Spekker fluorimeter. The washed yeast from $80 \mathrm{ml}$. toddy was suspended in $80 \mathrm{ml} .0 \cdot 1 \mathrm{~N}-\mathrm{HCl}$ and boiled for $\mathrm{I}$ min. Extraction of thiamine by boiling with $\mathrm{O} \cdot \mathrm{I} \mathrm{N}-\mathrm{HCl}$ for $30 \mathrm{~min}$, as recommended in certain published procedures, was omitted, because this treatment had been found to give low thiamine values when applied to yeast. The solution was adjusted to $\mathrm{pH} 4.5$ by the addition of $2.5 \mathrm{M}$-sodium acetate (bromocresol green as external indicator) and incubated with $500 \mathrm{mg}$ Takadiastase (Parke, Davis and Co.) at $50^{\circ}$ for $5 \mathrm{~h}$. Incubation at this temperature for $5 \mathrm{~h}$ was found to give the highest readings for thiamine. The volume was made up to $100 \mathrm{ml}$. with $\mathrm{O} \cdot \mathrm{I} \mathrm{N}-\mathrm{HCl}$ and the adsorption of the vitamin on Decalso F, its elution and estimation were carried out as described by the Analytical Methods Committee (195I). Duplicate determinations on the same sample showed good agreement and the recovery of added thiamine was satisfactory.

In assaying the fluid portion of toddy, roo ml. samples were boiled for I min, adjusted to $\mathrm{pH} 4.5$ and incubated with Takadiastase, as described above for yeast. 
On account of the low concentration of thiamine the whole extract was passed through a small adsorption column holding $2 \mathrm{~g}$ Decalso $\mathrm{F}$, and the vitamin was eluted with ro ml. acid $\mathrm{KCl}$ reagent.

Riboflavin. A modification of the method of Barton-Wright \& Booth (1943) was used. The yeast fraction from roo ml. toddy was suspended in $30 \mathrm{ml} .0 .25 \mathrm{~N}-\mathrm{H}_{2} \mathrm{SO}_{4}$ and autoclaved at ${ }_{1} \mathrm{lb}$. pressure for $\mathrm{I}_{5} \mathrm{~min}$; the $\mathrm{pH}$ was adjusted to 4.5 with $10 \%$ $\mathrm{NaOH}$ (bromocresol green as external indicator) and the volume was made up to $40 \mathrm{ml}$. with distilled water. After filtration through no. 5 Whatman paper, ro $\mathrm{ml}$. portions were each treated consecutively with I ml. glacial acetic acid, $0.5 \mathrm{ml} .2 \%$ $(\mathrm{w} / \mathrm{v}) \mathrm{KMnO}_{4}$ and $0.5 \mathrm{ml}$. Io vol. $\mathrm{H}_{2} \mathrm{O}_{2}$. The fluorescence was measured in a Spekker fluorimeter against a riboflavin solution containing $0.5 \mu \mathrm{g} / \mathrm{ml}$. 'Blank' determinations were carried out after exposing the extracts to direct sunlight for $3 \mathrm{~h}$. A calibration curve was constructed over a range of $0 . \mathrm{I}-0.5 \mu \mathrm{g}$ riboflavin $/ \mathrm{ml}$.

In analysing the fluid portion, $50 \mathrm{ml}$. were placed in a $125 \mathrm{ml}$. conical flask and I.25 ml. Io N- $\mathrm{H}_{2} \mathrm{SO}_{4}$ added (the final concentration of $\mathrm{H}_{2} \mathrm{SO}_{4}$ being about $0.25 \mathrm{~N}$ ). Two further samples were prepared in a similar manner; to one of them was added I and to the other $2.5 \mu \mathrm{g}$ riboflavin as an aqueous solution containing I $\mu \mathrm{g} / \mathrm{ml}$. After autoclaving, the riboflavin in the extracts was adsorbed on $0.5 \mathrm{~g}$ Superfiltrol (Filtrol Corporation, California) and eluted with $8 \mathrm{ml}$. pyridine-water-acetic acid mixture as described by Barton-Wright $\&$ Booth (1943). The extraction step with $n$-butyl alcohol was omitted and the fluorescence of the pyridine-water-acetic acid eluate was measured directly after treatment with $\mathrm{KMnO}_{4}$ and $\mathrm{H}_{2} \mathrm{O}_{2}$. The concentration of riboflavin was obtained by extrapolation of the straight line relating the fluorescences of the three extracts to their added riboflavin contents.

Nicotinic acid. In the extraction of the yeast portion, the residue from $100 \mathrm{ml}$. centrifuged toddy was suspended in $25 \mathrm{ml} .2 \mathrm{~N}-\mathrm{H}_{2} \mathrm{SO}_{4}$ in a boiling-tube and heated in a boiling water-bath for $90 \mathrm{~min}$. In assaying the fluid portion of toddy, $50 \mathrm{ml}$. were concentrated to about ro $\mathrm{ml}$. on the water-bath; after addition of $\mathrm{ro} \mathrm{ml}$. $\mathrm{Ca}(\mathrm{OH})_{2}$ reagent (Friedemann \& Frazier, 1950) the mixture was heated in a boiling water-bath for $90 \mathrm{~min}$. It was found that extraction of the fluid portion of toddy (which contained much sugar) with $\mathrm{Ca}(\mathrm{OH})_{2}$ gave higher values for nicotinic acid than those obtained by digestion with $\mathrm{H}_{2} \mathrm{SO}_{4}$. The rest of the procedure involving decolorization of the extracts with $\mathrm{Zn}(\mathrm{OH})_{2}$, colour development with metol and correction for 'blanks' were as described by Friedemann \& Frazier (1950). Photometric readings were made with a Spekker absorptiometer, and the calibration curve was prepared with a series of nicotinic-acid standards ranging from to to $50 \mu \mathrm{g} / \mathrm{ml}$. For many samples extracts were prepared with and without the addition of known amounts of nicotinic acid and the recovery was satisfactory.

Calcium. The method was a modification of the procedure described by the Imperial Bureau of Animal Nutrition (1937). The low Ca content necessitated the use of large samples and the yeast residue from $400 \mathrm{ml}$. toddy was incinerated in an electric muffle furnace. The fluid portion (200 ml. samples) was evaporated in small lots in a $50 \mathrm{ml}$. vitreosil basin before ashing. The $\mathrm{Ca}$ was precipitated as oxalate and titration carried out with $0.01 \mathrm{~N}-\mathrm{KMnO}_{4}$. 
Total and ionizable Fe. The yeast fraction and the liquid portion of toddy were analysed separately for total $\mathrm{Fe}$ after dry-ashing. Total $\mathrm{Fe}$ was determined as the ferrous-orthophenanthroline complex according to the method described by Pringle (1946), except that a $10 \%$ solution of hydroxylamine hydrochloride was used as reducing agent instead of $\mathrm{SO}_{2}$. For the estimation of ionizable $\mathrm{Fe}$ in the yeast fraction, the latter was suspended in dilute acetate buffer of $\mathrm{pH}_{5} 5$ and boiled for Io min (Shackleton \& McCance, 1936). The hydroxylamine and phenanthroline were then added and the mixture was allowed to stand overnight. After the addition of alcohol and centrifuging, the colour of the clear supernatant liquid was measured in the same way as for total $\mathrm{Fe}$. The fluid portion of toddy was clarified by the addition of $20 \%(\mathrm{w} / \mathrm{v})$ trichloroacetic acid and, after centrifuging, the clear supernatant liquid was used directly for measurement of ionizable $\mathrm{Fe}$.

\section{RESULTS}

Table I summarizes the results of the analyses of whole toddy for its major food components, acidity and alcohol content. The small amounts of protein and fat $(0.22 \mathrm{~g}$ and $0.04 \mathrm{~g} / 100 \mathrm{ml}$., respectively) are negligible from the dietetic standpoint if the beverage is consumed in moderation. The mean invert sugar content is $\mathrm{I} \cdot 94 \mathrm{~g} / \mathrm{I} 00 \mathrm{ml}$., sucrose $\mathrm{I} \cdot \mathrm{I} 3 \mathrm{~g} / \mathrm{I} 00 \mathrm{ml}$. and alcohol $5.0 \mathrm{I} \%(\mathrm{v} / \mathrm{v})$. The calculated energy value is approximately $270 \mathrm{Cal}$./pt. These figures show that the composition of coconut toddy in terms of its major components is similar to that of malt liquors in general.

The results of assays carried out on two samples of toddy for total and ionizable $\mathrm{Fe}$ are given in Table 2. About $40 \%$ of the total $\mathrm{Fe}$ in the yeast cells and almost all that in the liquid portion of toddy are in the ionizable form.

Table 3 shows the distribution of thiamine, riboflavin, nicotinic acid, $\mathrm{Ca}$ and $\mathrm{Fe}$ between the yeast cells and the liquid portion of toddy. Only $\mathrm{i} \cdot 3 \%$ of the thiamine is present in the liquid portion. This finding is not surprising, as yeast cells during growth are known to absorb thiamine from the nutrient environment. The fluid portion contains $25 \%$ of the total riboflavin and $59 \%$ of the total nicotinic acid. Almost all the $\mathrm{Ca}(96 \%)$ and a greater part of the $\mathrm{Fe}(70 \%)$ are found in the fluid portion of toddy.

\section{Table $\mathrm{I}$. Composition of whole toddy}

(Alcohol is expressed as \% (v/v), all other values as $\mathrm{g} / \mathrm{r} 00 \mathrm{ml}$.)

\begin{tabular}{|c|c|c|c|}
\hline & $\begin{array}{l}\text { No. of } \\
\text { samples }\end{array}$ & Range & Mean \\
\hline Ash & 6* & $0.25-0.31$ & 0.28 \\
\hline Crude protein $(\mathrm{N} \times 6.25)$ & 6* & $0.18-0.28$ & 0.22 \\
\hline Crude fat & $5^{*}$ & $0.04-0.05$ & 0.04 \\
\hline Invert sugar & 4 & $I \cdot 7 I-2 \cdot I I$ & $I \cdot 94$ \\
\hline Sucrose & 4 & $0.98-r .44$ & $I \cdot I 3$ \\
\hline Acidity (as acetic acid) & 6 & $0.37-0.50$ & 0.42 \\
\hline Alcohol & 5 & $4 \cdot 95-5 \cdot 38$ & 5.01 \\
\hline
\end{tabular}


Table 2. Total and ionizable iron in the yeast cells and the fluid portion of toddy

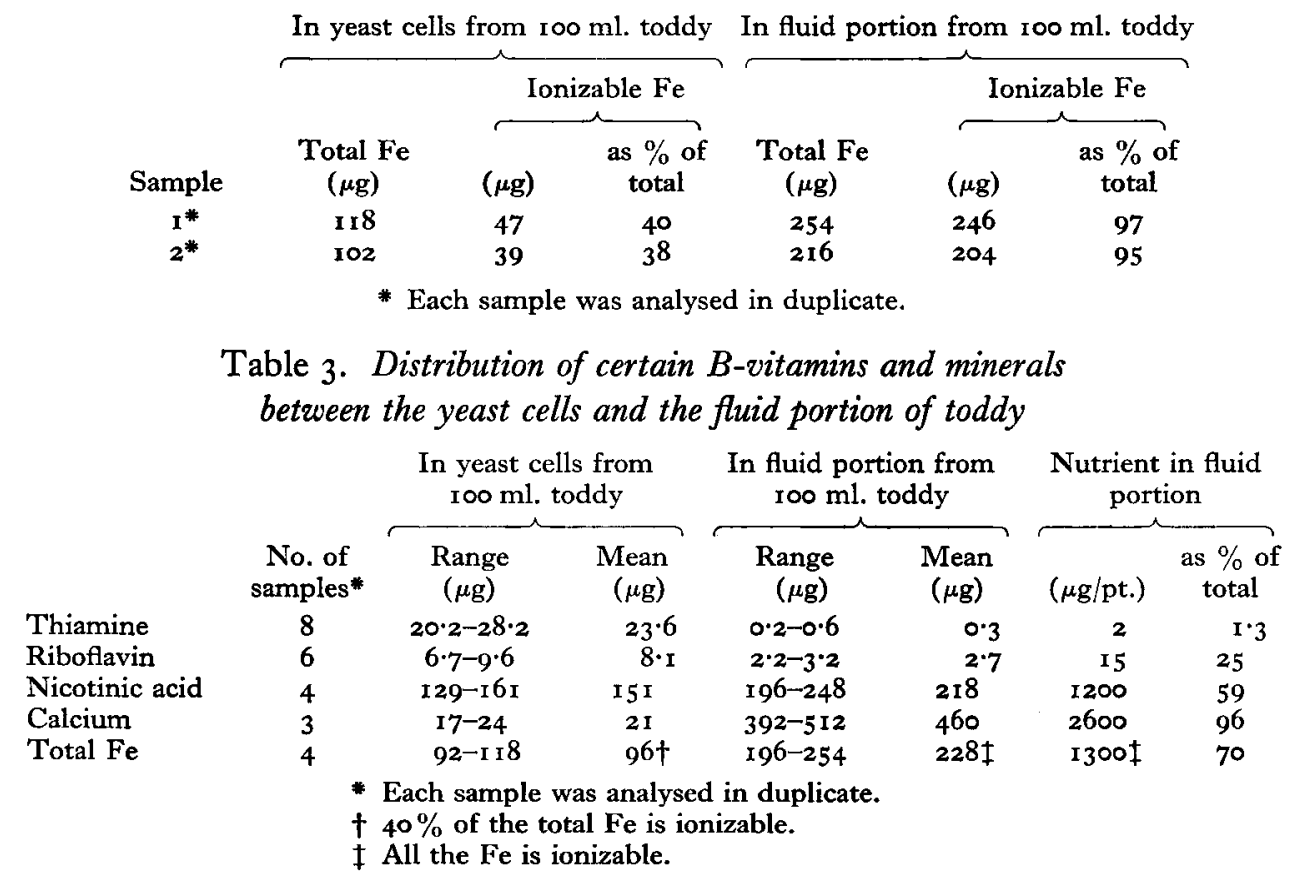

\section{DISCUSSION}

It will be evident that the chemical composition of toddy is affected by such factors as (I) the period of fermentation, (2) the types of fermenting agents present and (3) contamination by rain water entering the collecting pots. Possibly other factors, such as the condition of the tree, variety, climate and soil condition, will also have some effect on the composition. The results given in Table I are therefore not comparable with those recorded for coconut toddy by Gibbs (I9II) and by Browning $\&$ Symons (I9I6), as the various samples were analysed at different stages of fermentation. The present results, however, can be considered generally representative of toddy as consumed in the Government toddy-shops in Singapore.

Table 3 shows that the yeast cells present in roo ml. toddy contain $23.6 \mu \mathrm{g}$ thiamine, 8. $\mathrm{I} \mu \mathrm{g}$ riboflavin and ${ }_{15} \mathrm{I} \mu \mathrm{g}$ nicotinic acid. The dry weight of the yeast cells from Ioo ml. toddy is approximately $0.44 \mathrm{~g}$, so that calculated on a dry-weight basis the thiamine, riboflavin and nicotinic-acid contents are $5.4, \mathrm{I} \cdot 8$ and $34.3 \mathrm{mg}$ respectively/100 $\mathrm{g}$ dried yeast cells. These values are of the same order as those reported in the literature for unenriched dried yeasts. Since the toddy yeasts are not unusually rich in thiamine and riboflavin (compared with unenriched yeasts from other sources), it will be evident that the small amount of yeast in toddy will contribute little to the human requirement of these two vitamins. Calculation shows that a pint of toddy contains only $\mathrm{r} 35 \mu \mathrm{g}$ thiamine in the yeast fraction, and there is evidence (Hochberg et al. 1945) that the availability of thiamine in live yeast is only $17 \%$. The yeast 
fraction from a pint of toddy contains only $45 \mu \mathrm{g}$ riboflavin, and Price et al. (I947) have reported that the availability of riboflavin in fresh live yeast is only $9 \%$. There appears to be no experimental evidence on the extent to which nicotinic acid in live yeast is available to human subjects.

The results in Table 3 show that the fluid portion of toddy is a negligible source of thiamine $(2 \mu \mathrm{g} / \mathrm{pt}$.) and of riboflavin ( $15 \mu \mathrm{g} / \mathrm{pt}$.). The nicotinic acid present in the fluid portion of a pint of toddy is $1 \cdot 2 \mathrm{mg}$, which is about $10 \%$ of that recommended by the (U.S.A.) National Research Council (1948) as daily allowance.

A pint of toddy contains only $2.6 \mathrm{mg} \mathrm{Ca}$ and $\mathrm{I} \cdot 3 \mathrm{mg}$ ionizable $\mathrm{Fe}$ in its fluid portion (Table 3 ). Presumably all this $\mathrm{Fe}$ is available and will furnish about $10 \%$ of the recommended daily allowance. There is a possibility that a part of this $\mathrm{Fe}$ may have originated from the earthenware pots and also from the chipped enamelled measuring vessels that are used at the toddy-collecting centres. As mentioned earlier, about $40 \%$ of the total $\mathrm{Fe}$ in toddy yeast was found to be in the ionizable form. It is of interest to compare this figure with that obtained by Elvehjem, Hart \& Sherman (1933), who reported that $47 \%$ of the total $\mathrm{Fe}$ in a sample of yeast was in the available form (as determined by both chemical and rat-assay methods). However, even if $40 \%$ of the $\mathrm{Fe}$ in toddy yeast is available to human subjects, this small additional contribution

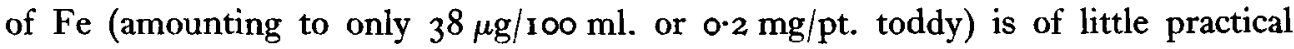
significance.

\section{SUMMARY}

I. Coconut toddy was analysed for ash, protein, fat, invert sugar, sucrose, acidity and alcohol.

2. The distribution of thiamine, riboflavin, nicotinic acid, calcium and iron between the suspended yeast cells and the fluid portion of coconut toddy was determined.

3. Almost all the thiamine in toddy was present in the yeast cells, but $25 \%$ of the riboflavin was in the fluid portion. A greater part of the nicotinic acid, $\mathrm{Ca}$ and $\mathrm{Fe}$ of toddy was found in the fluid portion, namely, 59, 96 and $70 \%$, respectively.

4. The consumption of coconut toddy in moderate quantities would not make any significant contribution to the human requirements for thiamine, riboflavin and $\mathrm{Ca}$.

5. The amounts of nicotinic acid and ionizable $\mathrm{Fe}$ in the fluid portion of a pint of toddy ( $1 \cdot 2 \mathrm{mg}$ and $\mathrm{I} \cdot 3 \mathrm{mg}$, respectively) would furnish about $10 \%$ of the recommended daily allowance.

I wish to thank Professor R. A. Robinson for his kind interest in this work and MrS. P. Ong for technical assistance.

\section{REFERENCES}

Analytical Methods Committee, Society of Public Analysts and Other Analytical Chemists (I951). Analyst, 76, 127.

Anonymous (194I). Health Bulletin, no. 23, 3rd ed. New Delhi: Manager of Publications.

Association of Official Agricultural Chemists (1950). Official and Tentative Methods of Analysis, 7 th ed. Washington, D.C.: Association of Official and Agricultural Chemists.

Barton-Wright, E. C. \& Booth, R. G. (1943). Biochem. F. 37, 25.

Browning, K. C. \& Symons, C. Y. (I9I6). F. Soc. chem. Ind., Lond., 35, I I 38. 
Elvehjem, C. A., Hart, E. B. \& Sherman, W. C. (1933). F. biol. Chem. 1o3, 6r.

Friedemann, T. E. \& Frazier, E. I. (1950). Arch. Biochem. 26, 36r.

Gibbs, H. D. (1911). Philipp. F. Sci. 6, I47.

Hochberg, M., Melnick, D. \& Oser, B. L. (1945). F. Nutr. 30, 201.

Imperial Bureau of Animal Nutrition (1937). Tech. Commun. Bur. Anim. Nutr., Aberd., no. 9.

Kingsley, H. N. \& Parsons, H. T. (r947). F. Nutr. 34, 32 I.

Lane, J. H. \& Eynon, L. (1923). F. Soc. chem. Ind., Lond., 42, 32T.

National Research Council (1948). Repr. nat. Res. Coun., Wash., no. I29.

Parsons, H. T., Williamson, A. \& Johnson, M. L. (1945). F. Nutr. 29, 373.

Price, E. L., Marquette, M. M. \& Parsons, H. T. (1947). F. Nutr. 34, 31 I.

Pringle, W. J. S. (1946). Analyst, 71, 490 .

Shackleton, L. \& McCance, R. A. (1936). Biochem. F. 30, 582 .

\title{
Hexosamine in Human and Cow's Milk
}

\author{
By CONSTANCE A. C. ROSS \\ University Department of Infectious Diseases and Knightswood Hospital, Glasgow
}

(Received 27 November 1952)

It is generally recognized that the incidence of diarrhoea and vomiting in infancy is much higher in babies receiving cow's milk than in those who are breast fed, but the precise roles played by infection and nutrition in this disease syndrome are still uncertain. As a result of the examination of the amino-acids excreted in the faeces of infants receiving these two kinds of milk it has already been suggested that the type of diet may be closely related to the establishment of certain types of Bacterium coli (Ross, 1951). During an investigation of the amino-acid composition of the protein from human and cow milk by means of paper chromatography it was frequently noticed that a spot appeared on chromatograms of hydrolysed human milk protein that was absent on those from the hydrolysed protein from cow's milk. The identification of this spot as a hexosamine and the probable reason for its occurrence is the subject of the present communication.

\section{EXPERIMENTAL}

Milk samples used for chromatography. (a) Human milk. Milk was obtained from five mothers at varying stages of lactation. The milk was taken with a breast pump at the same time each day and at least $4 \mathrm{~h}$ after the previous feed. Three samples were taken at each withdrawal, sample $A$ before the infant was put to the breast, and samples $B$ and $C$ after the child had suckled for 5 and 10 min, respectively. A pooled sample, D, was obtained by mixing equal parts of A, B and C. (b) Cow's milk. A representative sample was taken from the whole milking of two Ayrshire cows in mid-lactation, another from the bulk milk of a herd of thirty-six cows and two samples from the commercial milk supplied to the hospital. In addition, two samples of National Dried Milk, one a full-cream and the other a half-cream powder, were reconstituted to give a protein content equal to that of cow's milk. 